\title{
Larval development of Dagetichthys marginatus (Soleidae) obtained from hormone-induced spawning under artificial rearing conditions
}

\author{
ERNST F. THOMPSON ${ }^{1}$, NADINE A. STRYDOM ${ }^{2}$ and THOMAS HECHT ${ }^{1}$ \\ ${ }^{1}$ Department of Ichthyology and Fisheries Science, Rhodes University, P.O. Box 94, Grahamstown, 6139, South Africa. \\ E-mail: e.thompson@ru.ac.za or n.strydom@ru.ac.za \\ ${ }^{2}$ South African Institute for Aquatic Biodiversity, Private Bag 1015, Grahamstown, 6140, South Africa.
}

\begin{abstract}
SUMMARY: Dagetichthys marginatus (formerly Synaptura marginata) larvae were laboratory-reared from wild caught adult broodstock as part of an aquaculture research project in temperate South Africa. A larval description for the species is provided in this paper. This work also represents the first larval description for the genus Dagetichthys, which is represented by five species, three of which occur in the western Indian Ocean. Larval development in $D$. marginatus is typical of Soleidae. Dagetichthys marginatus larvae are heavily pigmented, with four characteristic melanophore "blotches" on the finfold. These larvae are easily distinguished from other soleid larvae commonly encountered in temperate South Africa based on the large size at flexion (5-7.06 mm BL) and the heavily pigmented body. Laboratory-reared postflexion larvae in this study showed similar meristic counts to those of wild caught adult fish. Despite the common occurrence of mature adults of this species in shallow marine waters off temperate South Africa, larvae are absent from nearshore ichthyoplankton catches. As yet, the spawning strategy of the species is unknown.
\end{abstract}

Keywords: Synaptura, fish larvae, description, temperate ichthyoplankton, soleids, aquaculture.

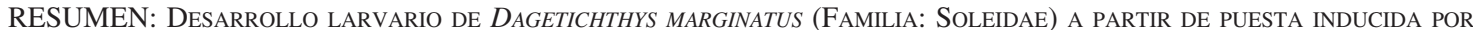
HORMONAS EN CONDICIONES DE CULTIVO ARTIFICIALES. - Las larvas de Dagetichthys marginatus (anteriormente Synaptura marginata) se cultivaron en el laboratorio a partir de adultos capturados en el medio natural como parte de un proyecto de investigación en la zona templada de Sudáfrica. En este trabajo se presenta la descripción de las larvas de esta especie. Este trabajo también representa la primera descripción del Dagetichthys, representado por cinco especies, tres de las cuales se encuentran en el Oeste del Océano Î́ndico. El desarrollo larvario de D. marginatus es el típico de la familia Soleidae. Las larvas de Dagetichthys marginatus están fuertemente pigmentadas con cuatro característicos bloques de melanóforos en la aleta primordial. Estas larvas se distinguen fácilmente de otras larvas de soleidos comúnmente encontradas en la zona templada de Sudáfrica en base a su gran longitud en el estadio de flexión (5-7.06 mm BL) y a su cuerpo fuertemente pigmentado. Las larvas en estado de postflexión obtenidas en el presente cultivo mostraron similares contajes que los adultos capturados en el medio natural. A pesar de la común aparición, en aguas someras, de adultos maduros de esta especie frente a la zona templada de Sudáfrica, las larvas estuvieron ausentes en las muestras de ictioplanton recolectadas en dicha zona. Hasta el momento, la estrategia de puesta de esta especie es desconocida.

Palabras clave: Synaptura, larvas de peces, descripción, ictioplancton de zonas templadas, soleidos, acuicultura.

\section{INTRODUCTION}

The white-margined sole, Dagetichthys marginatus, was identified as a suitable candidate species for aquaculture in South Africa, based on life history strategy (fecundity, maturity, egg size, inter alia), good natural growth rates and an established, lucrative market for flatfish (Thompson, 2004). Wild broodstock were successfully induced to spawn and the larvae were 
reared through to metamorphosis under controlled laboratory conditions.

Dagetichthys marginatus (Boulenger, 1900), formerly Synaptura marginata (Vachon et. al., in press), is one of 56 flatfish species that occur in southern African waters, 16 of which are soleids (Smith and Heemstra, 1986). The new soleid genus Dagetichthys consists of five species, three occurring in the western Indian Ocean (Vachon et. al., in press), namely $D$. marginatus, D. albomaculatus (Kaup, 1858) and D. commersonnii (Lacepède, 1802). The distribution of Dagetichthys marginatus is listed by Heemstra and Gon (1986) as extending from the Mozambique Channel southwards to Durban on the east coast of South Africa. However, Thompson (2004) recorded the distribution of $D$. marginatus to extend into temperate waters as far south as Gansbaai $\left(34^{\circ} 35^{\prime} \mathrm{S}, 19^{\circ} 20^{\prime} \mathrm{E}\right)$, where it is the most abundant shallow water sole species on intertidal and sub-tidal sandbanks.
Nothing is known about the early life history of this species prior to the allocation of this species to the genus Dagetichthys. An isolated report on egg size $(2.08 \mathrm{~mm})$ (Ochiai, 1966) was shown to be inaccurate due to the misidentification of adult fish (Vachon et. al., in press), while a record of three $D$. marginatus larvae (2.8-3.2 mm) (Beckley, 1986) in temperate South Africa remains unconfirmed. The only information for larvae of the 14 species in the genus Synaptura (Eschmeyer, 1998) was an isolated description for Synaptura kleinii (Brownell, 1979), which was subsequently moved to the genus Synapturichthys (Heemstra and Gon, 1986). Hence there are no published larval descriptions for the new genus Dagetichthys.

Laboratory rearing of D. marginatus for aquaculture provided an ideal opportunity to study and describe larval development. Understanding the critical changes in morphology and behaviour of this species, as well as the timing and duration of

TABLE 1. - Meristic, morphological and pigmentation (melanophore) information on soleid species occurring in South African waters for which larval descriptions are available (* denotes size at completion of flexion, while the others are size at commencement of flexion). Information provided is taken directly from literature cited (adapted from Wood, 2000).

\begin{tabular}{|c|c|c|c|c|c|}
\hline Species & $\begin{array}{l}\text { Myomeres (range for } \\
\text { preflexion and flexion) }\end{array}$ & Vertebra & $\begin{array}{r}\text { Size at } \\
\text { exion }(m\end{array}$ & Pigment & Reference \\
\hline Austroglossus microlepis & $56-58$ & $55-57$ & $5.2-5.5$ & $\begin{array}{l}\text { Dorsal and ventral midline; gut; } \\
\text { lower jaw; behind eyes; pectoral fins }\end{array}$ & $\begin{array}{l}\text { O’Toole, 1977; } \\
\text { Brownell, } 1979\end{array}$ \\
\hline Austroglossus pectoralis & $50-58(8-10+40-49)$ & 58 & $3.5-3.8$ & $\begin{array}{l}\text { Dorsal and ventral midline; fore- and } \\
\text { hind-brain; snout; lower jaw; ventral } \\
\text { and lateral gut; small spots on finfold }\end{array}$ & Wood, 2000 \\
\hline Dicologossa cuneata & $44-47(9+35-38)$ & $43-45$ & $6.3-6.5$ & $\begin{array}{l}\text { Dorsal and ventral midline; midbrain; } \\
\text { hindbrain; finfold; swim bladder, } \\
\text { gut; head }\end{array}$ & $\begin{array}{l}\text { Lagardère and } \\
\text { Aboussouan, } 1981\end{array}$ \\
\hline Heteromycteris capensis & $39-41(10+29-31)$ & $40-43$ & $6.2^{*}$ & $\begin{array}{l}\text { Midline body contour; Three spots on } \\
\text { ventral finfold; ventral gut wall; lower } \\
\text { pectoral fin margin }\end{array}$ & Brownell, 1979 \\
\hline Monochirus lutens & $36-38$ & $36-40$ & 5 & $\begin{array}{l}\text { Dorsal and ventral midline; midbrain; } \\
\text { posterior tail (early); finfold; ventral } \\
\text { abdominal wall }\end{array}$ & $\begin{array}{l}\text { Nichols, } 1976 \text { in } \\
\text { Olivar and Fortuño, } \\
1991\end{array}$ \\
\hline Monochirus ocellatus & $34-37(8-9+26-28)$ & $37-38$ & 4 & $\begin{array}{l}\text { Three dorsal and two ventral concen- } \\
\text { trations of small spots on finfold; caudal } \\
\text { tip; dorsal and ventral body contour }\end{array}$ & $\begin{array}{l}\text { Palomera and Rubies, } \\
1971 \text { in Olivar and } \\
\text { Fortuño, } 1991\end{array}$ \\
\hline Pegusa lascaris & $47(9+38)$ & $42-47$ & 5.3 & $\begin{array}{l}\text { Many small melanophores scattered over } \\
\text { head, body and fins. Heaviest concen } \\
\text { trations over lateral and ventral gut } \\
\text { surface and laterally on tail }\end{array}$ & $\begin{array}{l}\text { Clarke, } 1914 \text { in } \\
\text { Ahlstrom et al., 1984; } \\
\text { Russell, } 1976\end{array}$ \\
\hline Synapturichthys kleini & $42-45(9-10+33-35)$ & $46-47$ & $6.5^{*}$ & $\begin{array}{l}\text { Densely packed stellate melanophores } \\
\text { scattered over all body surfaces and finfold }\end{array}$ & Brownell, 1979 \\
\hline Dagetichthys marginatus & 40 (preflexion) & 42 & $5-7.6$ & $\begin{array}{l}\text { Three distinct clusters on the dorsal and } \\
\text { one on the ventral finfold and later on fins, } \\
\text { when the last dorsal and ventral cluster } \\
\text { fuses to form a band over the body }\end{array}$ & This study \\
\hline
\end{tabular}


each of these events, will facilitate larval rearing protocols.

Larval descriptions for coastal fishes are generally lacking in South Africa (Strydom and Neira, in press). Descriptions are, however, available for eight of the 16 soleid species occurring on the South African coast (Table 1). This paper presents the first description of the early larval development of the white-margined sole, D. marginatus (Boulenger, 1900). This information will assist in the identification of this species in ichthyoplankton samples and in so doing provide much-needed information on its spawning and its larval and juvenile distribution in coastal waters off South Africa.

\section{MATERIALS AND METHODS}

All broodstock fish were identified as Dagetichthys marginatus based on meristic counts given in Heemstra and Gon (1986) and Vachon et. al. (in press). Male and female fish were collected with a hand-held, multiprong spear between Port Elizabeth (33 $57^{\prime} S$; $\left.25^{\circ} 38^{\prime} \mathrm{E}\right)$ and Great Fish River

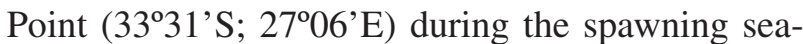
son (October to March) (Thompson, 2004) and transported to the marine hatchery at Rhodes University, Grahamstown. Females were induced to ovulate using Aquaspawn ${ }^{\circledR}$, a $\mathrm{GnRH}$ analogue (Millar's Clinical Laboratories, Touws River, South Africa) at a dosage of $0.5 \mathrm{ml}$ per $\mathrm{kg}$ of body weight. Eggs were obtained by strip-spawning the females approximately $38 \mathrm{~h}$ after the single hormone injection. Males were sacrificed and the testes were homogenized in a small volume $(1 \mathrm{ml})$ of saline solution $(0.9 \mathrm{ppt})$. Eggs were fertilized with the testicular homogenate. After fertilisation and hardening, eggs were thoroughly washed with seawater and divided among six $60 \mathrm{~L}$ black upwelling incubators at a density of $20 \mathrm{eggs} / \mathrm{L}$ for egg incubation and larval rearing. Hatching occurred between 42 and $49 \mathrm{~h}$ after fertilisation and exogenous feeding began three days after hatching (dah). Larvae were fed twice daily on newly hatched brine shrimp, Artemia salina nauplii, from first feeding to 16 dah. After this, larvae were fed two-day old, Super Selco (INVE) enriched A. salina. A new batch of enriched nauplii was provided every $24 \mathrm{~h}$ at a density of five individuals $/ \mathrm{ml}$. Temperature and salinity were kept constant at $19 \pm 0.8^{\circ} \mathrm{C}$ and $35 \mathrm{ppt}$, respectively, for the duration of egg incubation and larval rearing.
Although three successful larval batches were reared, larvae from only one spawning were used to avoid differences in broodstock condition and thus egg quality, which affect larval development (Bromage, 1995). Ten larvae were collected at specific intervals representing developmental endpoints after hatching. All samples were fixed in 5\% buffered formaldehyde for $24 \mathrm{~h}$ and then transferred into $70 \%$ ethanol. Representatives of the larvae examined and described in this paper were lodged in the national fish collection at the South African Institute of Aquatic Biodiversity (SAIAB 77531).

All terminology pertaining to larval fishes follows that of Neira et al. (1998). The term "larva" was used to designate all stages in the early life history from hatching to the attainment of a full fin ray complement, squamation and the subsequent loss of all larval characters, at which stage the "larva" becomes a "juvenile". Settlement stages still in possession of isolated larval characters and in a planktonic state were considered as larvae. Newly settled individuals were called "early juveniles" and were included in the study. The term "larva" was further subdivided into yolk-sac, preflexion, flexion and postflexion stages. The following body measurements were made for all developmental stages: body depth (BD), body length (BL), eye diameter (ED), head length (HL) and pre-anal length (PAL). All measurements were made according to Neira et al. (1998) to the nearest $0.01 \mathrm{~mm}$ using a Leica dissecting microscope fitted with an eyepiece micrometer for larvae $<10 \mathrm{~mm}$ and Vernier calipers for larger specimens. Body length (BL) represents notochord length in preflexion and flexion stage larvae, and standard length in postflexion larvae and early juveniles. All proportional values are a proportion of BL unless otherwise noted.

\section{RESULTS}

\section{Age and size range of developmental stages}

A total of 104 laboratory-reared larvae (2.09$14.75 \mathrm{~mm} \mathrm{BL}$ ) were examined to describe morphometrics, meristics and pigmentation. Newly hatched larvae $(0 \mathrm{~h})$ ranged in size between 2.09 and 2.19 $\mathrm{mm}$ BL. The yolk-sac was completely absorbed after 4 days, while the oil globules persisted for approximately 12 hours. Yolk-sac larvae ranged from 2.09 to $3.41 \mathrm{~mm} \mathrm{BL}$ (Table 2). The preflexion 
TABLE 2. - Body length and body proportions of the larval and settlement stages of Dagetichthys marginatus reared under laboratory conditions (n, number of larvae; BL, body length; HL, head length; BD, body depth; PAL, preanal length; SD, standard deviation).

\begin{tabular}{|c|c|c|c|c|c|c|}
\hline $\mathrm{n}$ & & $\begin{array}{c}\text { Yolk-sac } \\
40\end{array}$ & $\begin{array}{c}\text { Preflexion } \\
30\end{array}$ & $\begin{array}{c}\text { Flexion } \\
20\end{array}$ & $\begin{array}{c}\text { Postflexion } \\
10\end{array}$ & $\begin{array}{c}\text { Settlement } \\
4\end{array}$ \\
\hline $\mathrm{BL}$ & $\begin{array}{l}\text { Range } \\
\text { Average } \\
\text { SD }\end{array}$ & $\begin{array}{c}2.09-3.41 \\
2.79 \\
0.50\end{array}$ & $\begin{array}{c}3.44-5.15 \\
4.04 \\
0.48\end{array}$ & $\begin{array}{c}5.00-7.06 \\
5.96 \\
0.70\end{array}$ & $\begin{array}{c}9.50-11.60 \\
10.59 \\
0.57\end{array}$ & $\begin{array}{c}13.50-14.75 \\
14.03 \\
0.58\end{array}$ \\
\hline $\mathrm{HL}(\% \mathrm{BL})$ & $\begin{array}{l}\text { Range } \\
\text { Average } \\
\text { SD }\end{array}$ & $\begin{array}{c}12.35-17.14 \\
14.63 \\
1.12\end{array}$ & $\begin{array}{c}17.86-25.23 \\
21.17 \\
2.04\end{array}$ & $\begin{array}{c}22.02-28.04 \\
24.50 \\
1.45\end{array}$ & $\begin{array}{c}25.47-30.77 \\
27.95 \\
1.80\end{array}$ & $\begin{array}{c}26.32-31.19 \\
28.99 \\
2.04\end{array}$ \\
\hline $\mathrm{ED}(\% \mathrm{HL})$ & $\begin{array}{l}\text { Range } \\
\text { Average } \\
\text { SD }\end{array}$ & $\begin{array}{c}35.29-70.00 \\
52.74 \\
9.95\end{array}$ & $\begin{array}{c}28.57-45.00 \\
35.91 \\
3.66\end{array}$ & $\begin{array}{c}21.67-30.43 \\
25.92 \\
2.25\end{array}$ & $\begin{array}{c}15.63-23.21 \\
19.34 \\
1.94\end{array}$ & $\begin{array}{c}14.71-16.67 \\
15.43 \\
0.93\end{array}$ \\
\hline $\mathrm{BD}(\% \mathrm{BL})$ & $\begin{array}{l}\text { Range } \\
\text { Average } \\
\text { SD }\end{array}$ & $\begin{array}{c}10.09-19.12 \\
13.61 \\
3.02\end{array}$ & $\begin{array}{c}22.22-34.23 \\
26.59 \\
3.28\end{array}$ & $\begin{array}{c}28.44-36.28 \\
31.65 \\
1.96\end{array}$ & $\begin{array}{c}39.62-50.00 \\
44.99 \\
3.73\end{array}$ & $\begin{array}{c}30.70-33.05 \\
32.30 \\
1.10\end{array}$ \\
\hline PAL (\%BL) & $\begin{array}{l}\text { Range } \\
\text { Average } \\
\text { SD }\end{array}$ & $\begin{array}{c}42.20-62.69 \\
51.54 \\
6.84\end{array}$ & $\begin{array}{c}40.00-48.65 \\
43.52 \\
2.55\end{array}$ & $\begin{array}{c}42.59-49.56 \\
46.60 \\
1.89\end{array}$ & $\begin{array}{c}32.76-46.32 \\
39.65 \\
4.03\end{array}$ & $\begin{array}{c}22.88-25.93 \\
24.53 \\
1.26\end{array}$ \\
\hline
\end{tabular}

stage lasted for 6 days after yolk-sac absorption. During the preflexion stage the larvae ranged from 3.44 to $5.15 \mathrm{~mm}$ BL. Flexion of the notochord tip started 11 dah and was completed between 20 and 30 dah. Flexion stage larvae ranged from $5.00 \mathrm{~mm}$ (11 dah) to $7.06 \mathrm{~mm} \mathrm{BL} \mathrm{(15} \mathrm{dah).} \mathrm{The} \mathrm{smallest} \mathrm{post-}$ flexion larva measured $9.50 \mathrm{~mm} \mathrm{BL}$ at 30 dah.

\section{General morphology}

Larvae are elongate (Fig. 1A) in body shape during the yolk sac stage (mean $\mathrm{BD}=13.61 \%$ ), becoming more moderate (Fig. 1B) at the preflexion stage (mean BD $=26.59 \%)$. Body depth increases from the onset of flexion as the gut enlarges and coils prior to the settlement stage. Larvae remain moderately deep-bodied until metamorphosis into juveniles (BD 28.44-50.00\%). The head is compressed and small during the yolk-sac stage (HL 14.63\%), becoming moderate in size during later developmental stages (HL 21.17-28.99\%). The snout is short, giving the head a rounded, convex dorsal profile during preflexion and flexion (Fig. 1). A dorsal hump forms during the postflexion stage. This very distinct fleshy extension protrudes over the anterior, dorsal surface of the head and joins with the dorsal fin (Fig. 1D). The head and snout profile becomes convex after eye migration is complete. Both body depth and head length increase proportional to BD during development. Pre-anal length gradually decreases throughout development, from long to moderate (PAL 62.69-32.76\%) during early stages to short (mean PAL 24.53\%) at the settlement stage (Table 2).

Newly hatched larvae have a moderate to large, unsegmented yolk-sac (0.50-0.59 mm diameter). In excess of 50 oil globules are distributed in the yolksac and are clustered together in groups of eight or less situated at the posterior end of the yolk-sac. An additional dense cluster of about 30 oil globules is also situated at the posterior end of the yolk-sac. Prior to first feeding, the oil globules fuse to form one large globule situated in a posterior-dorsal position in the reduced yolk-sac. The eyes are unpigmented in yolk-sac larvae and become fully pigmented and functional in early preflexion larvae by $3.44 \mathrm{~mm}$. The mouth becomes functional at the same time as the gut is fully formed in preflexion larvae at 3 dah (3.44 mm BL) and larvae start feeding on Artemia salina 4 dah. Two to five small villiform teeth were first observed at 16 dah $(6.60 \pm 0.27$ $\mathrm{mm} \mathrm{BL}$ ) on the blind and ocular side of the dentary. Villiform teeth are present on the premaxilla at 31 dah, while the number of teeth on the blind side dentary increases. At this stage, the teeth on the ocular side dentary disappear. No further teeth develop on the ocular side premaxilla at any stage during development (Ende, in prep.). Preflexion larvae have a myomere count of 40 , while the vertebral count is 42 after ossification. Myomeres could not be counted during any other larval stage due to heavy pigmentation. The air bladder is visible in isolated larvae 7 dah and not in older larvae due to heavy pigmentation. Larvae are, however, positively buoyant until 
(A) $2.13 \mathrm{~mm} \mathrm{BL}$
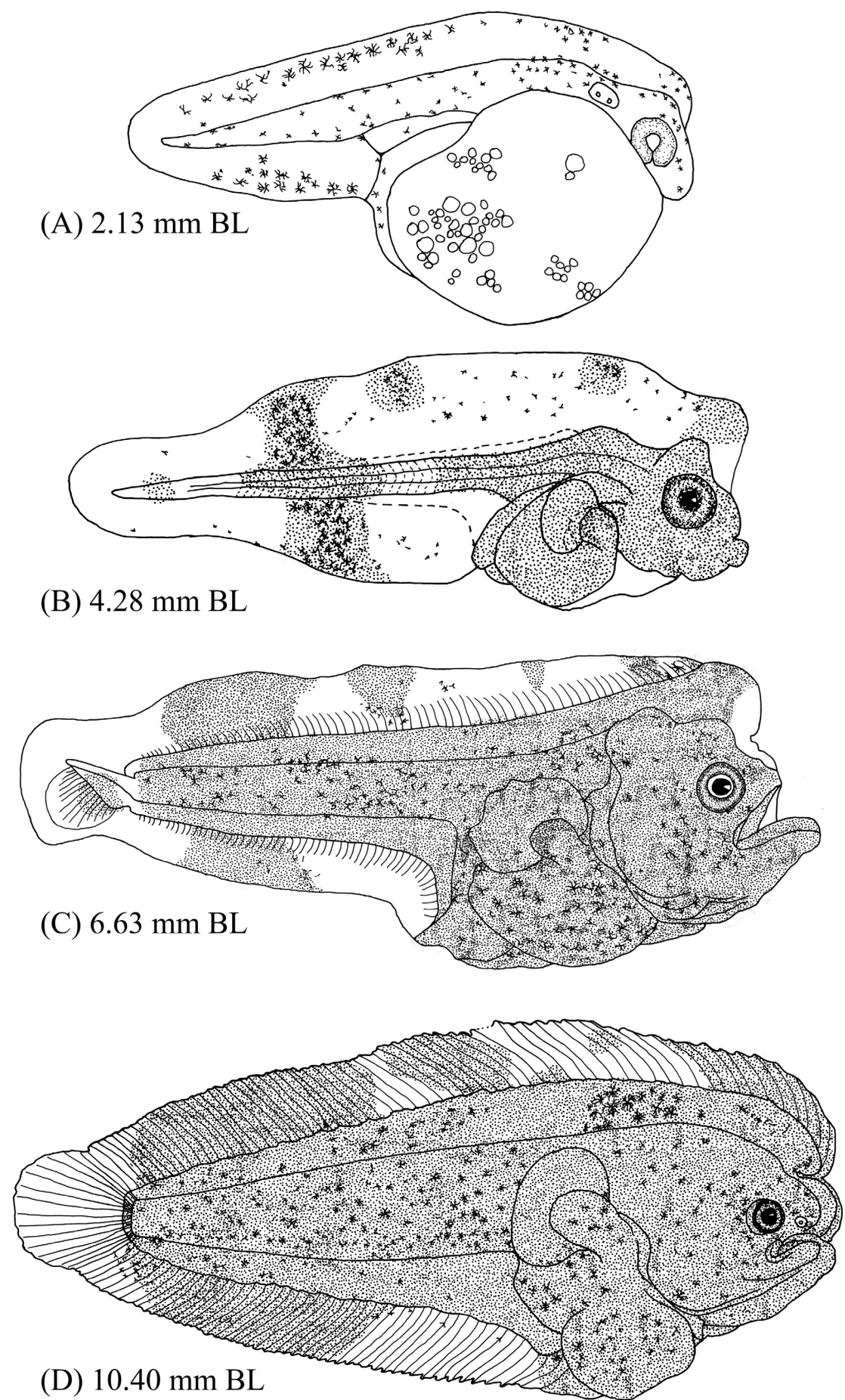

FIG. 1. - Larvae of laboratory-reared Dagetichthys marginatus. (A) newly hatched yolk-sac stage (myomeres, although present, were too indistinct to draw accurately). (B) preflexion. (C) flexion. (D) postflexion.

flexion, after which they become substratum-associated. This indicates the presence and use of an air bladder during the early stages of larval development. The gill membrane is also free from the isthmus at this stage. No head spination is present at any stage of development.

\section{Development of fins}

Pectoral fin buds appear in late yolk-sac or early preflexion larvae from $3.03 \mathrm{~mm}$ BL. These increase in size throughout development up to settlement (13.52 $\mathrm{mm} \mathrm{BL}$ ), when the fins decrease in size and 


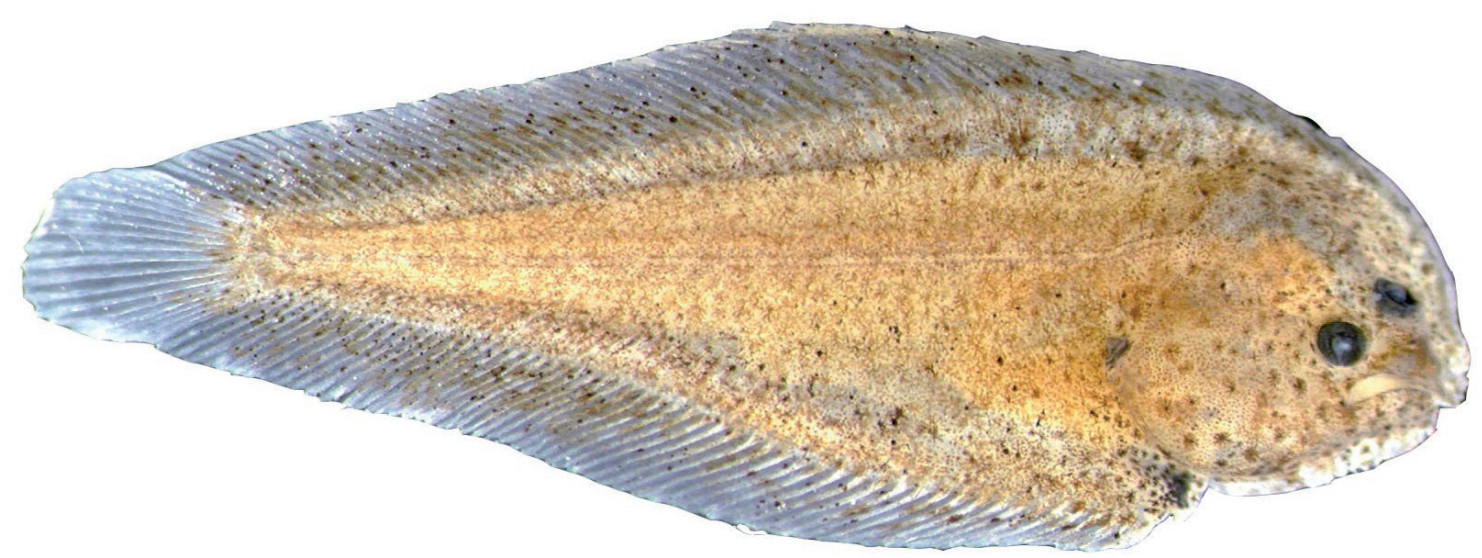

FIG. 2. - Settlement stage larva of Dagetichthys marginatus $(10.53 \mathrm{~mm} \mathrm{BL})$ reared under laboratory conditions.

seven pectoral-fin rays develop on both the ocular and blind sides. Paired pelvic-fin buds start developing during the late flexion stage from $6.50 \mathrm{~mm} \mathrm{BL}$ (15 dah) and are fully developed in early settlement stage larvae from $13.52 \mathrm{~mm} \mathrm{BL}$, with 3 rays present. The dorsal, caudal and anal-fin anlagen appear simultaneously in late preflexion larvae by $4.72 \mathrm{~mm}$ BL. Incipient rays form during early flexion and a full adult ray complement (D 70, A 55, C18) is present by late flexion stages from $6.13 \mathrm{~mm}$ BL (15 dah). The dorsal, caudal and anal fin membranes remain fused throughout development and in adults. No fin spines or extraordinary rays are present in Dagetichthys marginatus larvae during any stage of development.

\section{General pigmentation pattern during development}

Pigmentation increases from sparsely pigmented yolk-sac larvae to heavily pigmented settlement stage larvae. The general pattern of occurrence of melanophores on the head and trunk remains similar from first feeding ( $3 \mathrm{dah}$ ) to postflexion larvae, although intensity and melanophore type (e.g. punctate and/or stellate) increase with development (Fig. 1). Distinctive melanophores are described in the text but the body of the larva is also covered with very small punctuate melanophores that are randomly distributed in the areas as shown in Figure 1. Xanthophores (not indicated in Fig. 1 as these disappear in preserved specimens) dominate the pigmentation of live yolk-sac larvae, mirroring the melanophore pattern observed in four-day-old larvae. Xanthophores, however, decrease in number and intensity until they disappear completely around
4 dah and are replaced by branched, stellate melanophores.

\section{Head pigmentation}

Head pigmentation is characterised by melanophores on the lower lip (extending along the lower jaw line in later stages), preopercle, behind the eye and the isthmus in preflexion larvae, increasing in number and intensity in flexion larvae. In some flexion specimens, a melanophore ring appears around the eye. Postflexion larvae lose this general pattern of pigmentation, as the whole head region becomes covered with many random melanophores. An isolated group of internal melanophores is visible at the join of the lower and upper jaw, as well as on the dorsal hump of the head in preflexion larvae.

\section{Trunk and tail pigmentation}

Trunk pigmentation in early preflexion larvae consists of three large clusters of melanophores or "blotches" on the dorsal finfold and one on the ventral finfold (Fig. 1B). The first of the dorsal blotches is situated anterior to the nape, the second occurs opposite the anal opening (midway down the trunk) and the third occurs two thirds along the length of the trunk. The ventral blotch is in line with the third dorsal blotch. This third dorsal and the ventral blotch expand laterally over the trunk, across the myomeres, until the two fuse and become an "hourglass shaped" band across the larva during late preflexion. This band widens during flexion to form one solid band and continues to be visible as a "dusky bar" in postflexion larvae. The first two dorsal blotches remain visible during and after fin ray 
development. In live larvae, iridiophores overlay the melanophore pattern of the three dorsal blotches at the start of flexion and continue to exist until the end of flexion. The notochord, during preflexion, is sparsely pigmented with punctuate melanophores that become heavily stellate during flexion, covering almost the entire thickening of the myomeres. With this thickening during flexion, internal pigmentation appears on the ventral side along the notochord and above the gut, and become increasingly difficult to see as the external pigmentation develops. The gut is even, but lightly pigmented in preflexion larvae. This pigmentation pattern remains the same although individual melanophores expand and the pigmentation becomes heavy, concealing any internal pigmentation that might be present in and around the gut during flexion and later stages of the development. Pelvic fins become pigmented with melanophores during the postflexion stage and remain so through to the juvenile stage. The base of the pectoral fin becomes pigmented during preflexion stages.

A cluster of melanophores appears on and around the notochord, anterior to the tip, during the preflexion stage and disappears at the end of flexion. Other than this cluster, the caudal peduncle and caudal fin remains free of melanophores.

\section{DISCUSSION}

Dagetichthys marginatus larvae follow the typical pattern of soleid development (Leis and Trnski, 2000). Fin development as well as the lack of extraordinary long rays and spines is characteristic. The anterior dorsal fin supports (pterygiophores and the proximal portion of rays) form a deep notch with the top of the snout and head of postflexion larvae. The eye migrates through this notch and the notch closes following eye migration. This anterior extension of the dorsal hump on the head is, however, not common among soleids. The only other described larval soleid with a similar morphological feature is Heteromycteris japonicus (Ahlstrom et al., 1984).

All the larvae used for this description were laboratory-reared from eggs, which according to Watson (1982) may result in heavier pigmentation. Laboratory reared larvae may also show slightly different meristic characteristics to those of wildcaught individuals. Variable laboratory rearing conditions can manifest in those characteristics that are partially controlled by environmental conditions, such as vertebral and fin ray counts (Hunter 1984). In this study, however, fin ray and vertebral counts observed in laboratory-reared larvae fell within the range for wild-caught adult Dagetichthys marginatus; D 70-81, A 55-64, P 7, C 18, V 42-45 (Vachon et.al., in press).

Dagetichthys marginatus larvae are easily distinguished from other pleuronectiform larvae commonly found in temperate nearshore waters of South Africa. The larvae of the cynoglossid, Cynoglossus capensis (Brownell, 1979) are easily distinguishable from those of $D$. marginatus by four elongated anterior dorsal rays that only start disappearing in late postflexion stages. At this stage $C$. capensis is a lefteyed (sinistral) flatfish, while D. marginatus is righteyed (dextral). Similarly, Cynoglossus zanzibarensis (Wood, 2003) can be distinguished from D. marginatus by two elongated anterior dorsal fin rays up to flexion, after which it becomes a sinistral flatfish. Other characteristics that could be used to make a distinction between Cynoglossidae and D. marginatus are the higher meristic counts, a coiled gut and a single pelvic fin (Leis and Carson-Ewart, 2000).

Except for Arnoglossus capensis and Pseudorhombus arsius, bothid larvae are not commonly found in ichthyoplankton samples in temperate coastal waters of South Africa (Strydom, unpublished data). The larvae of $A$. capensis have been partially described by Brownell (1979). Despite the paucity of descriptive information, $D$. marginatus can be distinguished from bothids by the presence of a continuous dorsal, caudal and anal fin membrane that remains fused until the fin rays ossify. Other notable bothid characteristics are the elongated dorsal fin rays during early larval stages and the fact that they are sinistral flatfish.

Soleids commonly encountered in temperate inshore waters of South Africa are Heteromycteris capensis, Solea turbynei (formerly S. bleekeri) and Austroglossus pectoralis (Table 1). The larvae of $A$. pectoralis and $S$. turbynei are notably smaller than those of D. marginatus, reaching flexion at a size of 3.5-3.8 mm (Wood, 2000) and $\sim 3.5-3.9 \mathrm{~mm}$ (Strydom, unpublished data.), respectively, whereas D. marginatus range from 5 to $7.06 \mathrm{~mm} \mathrm{BL}$ at flexion. A. pectoralis and H. capensis larvae are light to moderately pigmented, $S$. turbynei larvae are moderate to heavily pigmented and $D$. marginatus larvae are heavily pigmented. Postflexion larvae of all these species can also be separated by fin ray counts. 
Dagetichthys marginatus can also be separated from $H$. capensis by the presence of the fused anal, caudal and dorsal fins. Synapturichthys kleini (Brownell, 1979) has a very different melanophore arrangement to $D$. marginatus, although fin ray counts and sizes at different developmental stages are similar. Synapturichthys kleini has densely packed stellate melanophores scattered randomly over the body and finfold, while D. marginatus has a distinctive melanophore pattern with four characteristic melanophore blotches on the finfold.

The actual spawning habitat of $D$. marginatus has not been identified, mainly due to the lack of eggs, larvae and juveniles in shallow surf or nearshore plankton catches (Lasiak, 1983, 1984; Strydom, 2003; Watt-Pringle and Strydom, 2003) and the lack of larval fish research in offshore waters of South Africa. Although there is no evidence to suggest a spawning migration given the prevalence of mature females intertidally, it is not unlikely among flatfish, as Dagang et al. (1992) and Shuozeng (1995) showed this to be the case for most flatfish species in the Yellow Sea, China. Further research is required on soleid spawning strategies off temperate South Africa.

\section{ACKNOWLEDGEMENTS}

The authors would like to thank the National Research Foundation, South Africa and DAAD, Germany for funding this research. Ms Elaine Heemstra is thanked for valuable advice with drawing the larval stages.

\section{REFERENCES}

Ahlstrom, E.H., K. Amaoka, D.A. Hensley, H.G. Moser and B.Y. Sumida. - 1984. Pleuronectiformes: Development. In: H.G. Moser, W.J. Richards, D.M. Cohen, M.P. Fahay, A.W. Kendall $\mathrm{Jr}$ and S.L. Richardson (eds.), Ontogeny and Systematics of Fishes. Am. Soc. Ichthyol. Herpetol., Spec. Publ., 1: 565-573.

Beckley, L.E. - 1986. The ichthyoplankton assemblage of the Algoa Bay nearshore region in relation to coastal zone utilization by juvenile fish. S. Afr. J. Zool., 21(3): 244-252.

Bromage, N.R. - 1995. Broodstock management and egg and larval quality. Oxford Blackwell Scientific.

Brownell, C.L. - 1979. Stages in the early development of 40 marine fish species with pelagic eggs from the Cape of Good Hope. Ichthyol. Bull. J.L.B. Smith Inst. Ichthyol., 40: 1-84.

Dagang, C., L. Changan and D. Shuozeng. - 1992. The biology of flatfish (Pleuronectinae) in coastal waters of China. Neth. J. Sea Res., 29(1-3): 25-33.

Eschmeyer, W.N. - 1998. Catalog of Fishes. California Academy of Sciences, San Francisco. Axcess updated internet site 17 April 2006.

Heemstra, P.C. and O. Gon. - 1986. Family No. 262: Solidae. In: M.M. Smith and P.C. Heemstra (eds.), Smiths' Sea Fishes. Southern Book Publishers, Johannesburg.

Hunter, J.R. - 1984. Synopsis of culture methods for marine fish larvae. In: H.G. Moser, W.J. Richards, D.M. Cohen, M.P. Fahay, A.W. Kendall Jr and S.L. Richardson (eds), Ontogeny and Systematics of Fishes. Am. Soc. Ichthyol. Herpetol., Spec. Publ., 1: 24-27.

Lagardère, F. and A. Aboussouan. - 1981. Développement du céteau, Dicologoglossa cuneata (Moreau, 1881) (Pisces, Pleuronectiformes, Soleidae): II. - Description des larves, Cybium, 5(2): 53-72.

Lasiak, T.A. - 1983. Recruitment and growth patterns of juvenile marine teleosts caught at King's Beach, Algoa Bay. S. Afr. J. Zool., 18(1): 25-30.

Lasiak, T.A. - 1984. Structural aspects of the surf-zone fish assemblages at King's Beach, Algoa Bay, South Africa: Long-term fluctuations. Coast. Shelf Sci., 18(3): 459-483.

Leis, J.M. and B.M. Carson-Ewart - 2000. The Larvae of IndoPacific Coastal Fishes: an identification guide to marine fish larvae. Brill, Leiden.

Leis, J.M. and T. Trnski. - 2000. Chapter 118 Soleidae (Soles). In: J.M. Leis and B.M. Carson-Ewart (eds.), The Larvae of IndoPacific Coastal Fishes: an identification guide to marine fish larvae. Brill, Leiden.

Neira, F.J., Miskiewicz, A.G. and T. Trnski. - 1998. Larvae of temperate Australian fishes. Laboratory Guide for larval fish identification. University of Western Australia Press, Nedlands.

Ochiai, A. - 1966. Studies on the comparative morphology and ecology of the Japanese soles. Spec. Rep. Mar. Biol. Inst. Kyoto Univ., 3: 1-97.

Olivar, M.P. and J.M. Fortuño. - 1991. Guide to ichthyoplankton of the southeast Atlantic (Benguela Current Region). Sci. Mar., 55(1): 1-383.

O’Toole, M.J. - 1977. Development and distributional ecology of the larvae of the West Coast Sole Austroglossus microlepis. Fish. Bull.S. Afr., 9: 32-45.

Russel, F.S. - 1976. The eggs and planktonic stages of British marine fishes. Academic Press, London.

Shuozeng, D. - 1995. Life history cycles of flatfish species in the Bohai Sea, China. Neth. J. Sea Res., 34(1-3): 195-210.

Smith, M.M. and P.C. Heemstra. - 1986. Smiths' Sea Fishes. Southern Book Publishers, Johannesburg.

Strydom, N.A. - 2003. Occurrence of larval and early juvenile fishes in the surf zone adjacent to two intermittently open estuaries, South Africa. Environ. Biol. Fish., 66: 349-359.

Strydom, N.A. and F.J. Neira. - (in press). Description and ecology of larvae of Glossogobius callidus and Redigobius dewaali (Gobiidae) from temperate South African estuaries. Afr. Zool.

Thompson, E.F. - 2004. Screening of the white margined sole, Synaptura marginata (Soleidae), as a candidate for aquaculture in South Africa. MSc Thesis, Rhodes University.

Vachon, J., Chapleau, F. and M. Desoutter. - (in press). Révision taxonomique et phylogénie des genres Dagetichthys et Synaptura sensu Chabanaud, 1928 (Soleidae; Pleuronectiformes). Cybium.

Watson, W. - 1982. Development of eggs and larvae of the white croaker, Genyonemus lineatus Ayres (Pisces; Sciaenidae) off the southern California coast. Fish. Bull. U.S., 80: 403-417.

Watt- Pringle, P. and N.A. Strydom. - 2003. Habitat use by larval fishes in a temperate South African surf zone. Estuar. Coast. Shelf Sci., 58: 765-774.

Wood, A.D. - 2000. The description of Austroglossus pectoralis (Teleostei: Soleidae) larvae from the south-east coast of South Africa. Sci.Mar., 64(4): 387-392.

Wood, A.D. - 2003. Description of larval Cynoglossus zanzibarensis (Teleostei: Cynoglossidae) from the Tsitsikamma coast, South Africa. Afr. J. Mar. Sci., 25: 177-183.

Scient. ed.: M.P. Olivar.

Received September 8, 2006. Accepted March 16, 2007.

Published online June 15, 2007. 